\title{
Goal Orientation \& Metacognitive Self-Regulation Students on Discourse Learning
}

\section{Deasyanti ${ }^{*}$, Santi Yudhistira ${ }^{2}$}

1,2 Program Studi Psikologi, Universitas Negeri Jakarta, Jakarta

*e-mail: deasyanti@unj.ac.id

\begin{abstract}
Corona Virus Disease 2019 (COVID-19) has impacted throughout all aspects of human life including education. Despite the previously applied distance education or e-learning in the conventional education, nowadays this instructional model became a newly common approach in education. Therefore, students have to make some adjustments in their learning approach in order to reach out their learning goals. Self-regulated learning (SRL) is a process of monitoring and controlling learning behaviors to achieve learning goals. One of the key factors that contribute to SRL is achievement goal orientation. The aim of this study is to find out the role of types of goal orientation towards metacognitive self-regulation. A total of 320 undergraduate students participated in this study. The findings showed that performance approach and performance avoidance were the significant predictors of metacognitive self-regulation. Students' preferences to performance goal-orientations were associated with the preliminary study findings that the new instructional model was related to decreased students' efficacy in learning and feelings of uncertainty to their academic achievement.
\end{abstract}

Keywords: Goal Orientation, Self-Regulated Learning

\section{Introduction}

Since the COVID-19 pandemic in Indonesia in early March 2020, there have been drastic changes in various sectors of life, including the higher education sector (Adedoyin \& Soykan, 2020; Fitriyani et al., 2020). During the handling of COVID-19, the Indonesian government, through the circular letter of the Ministry of Education and Culture number 15 of 2020 , stipulated education from home or learning from home and using distance learning methods through bold media (Dewi, 2020; Fitriyani et al., 2020; Yoga Purandina \& Astra Winaya, 2020). Online media in learning has become a medium used globally in various countries. This fast change in learning media requires students to adjust various things related to their learning process (Maatuk et al., 2021; Permai et al., 2021; Yudiawan, 2020). Changes in the media from face-to-face to bold caused a change in the interaction pattern between lecturers and students, between students, and differences in the method of delivering material (Kuo et al., 2014). The current learning concept is not entirely similar to the distance learning concept, namely learning that allows students to have their study time arrangements at home (Neroni et al., 2018; Yoga Purandina \& Astra Winaya, 2020).

Various studies have found that students experience many challenges and obstacles during distance learning (Sadikin \& Hamidah, 2020; Simanjuntak et al., 2020). A preliminary study conducted by researchers related to obstacles during lectures with PJJ to 144 students at one of the universities in Jakarta revealed several obstacles related to the learning process and technical obstacles such as learning devices and internet networks (Yudhistira et al., 2020). Some of the problems identified were unfavorable housing conditions, such as a crowded and noisy home environment. There is no precise time limit between lecture activities and rest time; more lecture assignments than during conventional learning. Students have difficulty prioritizing task completion, and boredom felt by students reduces learning motivation to take online classes. Students also perceive distance learning to be less effective in understanding lecture material, so that students worry about the final result of their academic achievement. With these various obstacles, students need to adjust to new

\footnotetext{
${ }^{*}$ Corresponding author.
}

Received January 22, 2021; Accepted May 22, 2021; Available online December 25, 2021

This is an open access article under the CC BY-SA license. Copyright $(2021$ by Author. Published by Universitas Pendidikan Ganesha 
learning situations to overcome the problems they face and achieve the expected learning goals (Hamidaturrohmah \& Mulyani, 2020; Hapsari \& Fitria, 2020; Suriadi et al., 2021). In other words, students must re-regulate the approach in their learning activities.

The active and constructive process within the individual, which personally and systematically monitors and controls his cognition, motivation, and behavior so that it is focused on achieving personal goals in learning, is known as the concept of self-regulated learning (J. Broadbent \& Poon, 2015; Van Alten et al., 2020). Self-regulated learning (SRL) is related to internal processes and is also related to contextual characteristics or external factors in the environment (Ahmed, 2017; Reni \& Kuswandi, 2018). To be successful in distance learning, students are expected to have a better $S R L$. It is necessary because when compared to conventional learning, distance learning is more learner-centered so that it demands more responsibility and independence, especially when learning takes place asynchronously. Studies on SRL have various theoretical models and have different discussions (Panadero, 2017; Winne, 2015). This study refers to the SRL model from discussing the four components of SRL, namely cognition, motivation, behavior, and context (Mawardi, 2020; Ranti et al., 2017). Compared to various theoretical models of SRL, Pintrich's model is more widely used in various studies (Panadero, 2017). The focus of SRL in this study is the cognitive component, namely the control of various cognitive strategies in learning, such as deep or superficial information processing, changes in learning strategies to suit the task's demands (Al-Harthy et al., 2010).

Controlling this cognitive strategy is called metacognitive self-regulation (Dent \& Koenka, 2016; Vrieling et al., 2012). Metacognitive processes are central to SRL, and metacognitive skills will be beneficial, especially in online learning environments that have flexible learning structures. The study found differences in the SRL of students who studied with different learning contexts, for example, between online, blended, and face-to-face learning (Jaclyn Broadbent, 2017; Sangsawang, 2020). It confirms that SRL is highly contextual and specific (Anthonysamy et al., 2020; Credé \& Phillips, 2011). To change the learning context during the COVID-19 pandemic from the conventional approach to PJJ, SRL adjustments are needed to achieve learning objectives optimally. In other words, a person's learning goals or objectives will direct his $S R L$, although the $S R L$ process itself can change dynamically to affect the learning objectives.

Learning goals or objectives are known as the concept of goal orientation (GO). There are various theoretical models of GO that use different terms but examine the same construct (Bittner, 2021; Hulleman et al., 2010). Two terms commonly used in GO theory will be used in this study, namely mastery goals and performance goals. Recent developments regarding the theoretical framework of GO distinguish two approaches to each of these goals, namely approach, and avoidance so that the combination forms four types of GO, namely mastery approach, mastery avoidance, performance-approach, and performanceavoidance (Elliot \& McGregor, 2001; Lin, 2020). The thing that distinguishes mastery and performance is how competence is defined. The mastery goal is a goal that focuses on developing competence through mastery of material which is measured based on one's standards, while the performance goal focuses more on displaying competence compared to others (Minelli et al., 2021; Moning \& Roelle, 2021). Approach and avoidance approach related to the positive or negative valence of competence. Positive valence if competence is defined as the probability that something desired will occur (e.g., success) or is considered to have negative valence if it is interpreted as the possibility of something undesirable happening (e.g., failure). Individuals with the GO mastery approach will focus on learning, overcoming challenges, or increasing competency levels, while the focus of mastery avoidance is to avoid appearing to have learned or mastered something less. Individuals with the GO performance approach strive to perform better than others and get positive evaluations from the environment. Meanwhile, performance avoidance tries not to appear incompetent or get a bad judgment from others (Elliot \& McGregor, 2001; Lin, 2020).

Various studies have proven the relationship between $\mathrm{GO}$ and $\mathrm{SRL}$, but there are still few that specifically examine the relationship between $\mathrm{GO}$ and metacognitive self-regulation (SR metacognitive) (Al-Harthy et al., 2010). Research on GO or SRL has been widely carried 
out in conventional educational settings, while in PJJ settings, it is still limited (Broadbent \& Poon, 2015; Neroni et al., 2018). This research will add to the study of GO and SRL in the context of PJJ, which is currently still a relatively new learning experience for students during the COVID-19 pandemic because previously, they were used to conventional or face-to-face learning. The distance learning method (PJJ) with online media requires students to be more independent in learning because the characteristics of online learning require students to be able to direct their learning (Serdyukov \& Hill, 2013). Therefore, differences in learning media will have implications for differences in SRL (Broadbent, 2017). This study aimed to determine the description of GO adopted by students and the metacognitive description of SR. Next, we specifically want to know which type of GO is the strongest predictor of SR metacognition in the context of PJJ. The results of this study are expected to provide information about the type of GO that students should adopt to carry out the most adaptive metacognitive strategies in their learning process. In addition, these results will have implications for how the structure of class goals or learning environments can stimulate GO types that are more adaptive to academic achievement.

\section{Method}

This study uses a survey as a data collection method and uses a quantitative approach, namely multiple regression analysis for data processing. The sampling technique used is convenience, where subjects are selected based on practical criteria, namely ease of access due to subjects' availability and willingness to become research participants (Etikan et al., 2016). The questionnaire was compiled in a google form and distributed through social media. The subjects of this research are students of one of the faculties at University $X$ in Jakarta, totaling 320 people. Male students were as many as 65 people (20.31\%) and female students as many as 255 people (79.69\%). The number of subjects that are not balanced between men and women is by the characteristics of the student population in certain faculties, which are more female students than male students. The age of the subjects was in the range of $18-22$ years.

The instrument used to measure SRL is the Motivated Strategies for Learning Questionnaire (Pintrich dkk, 1991). The complete instrument consists of 81 statements which are divided into several sub-scales, namely intrinsic goal orientation, extrinsic goal orientation, task values, control of learning beliefs, self-efficacy for learning and performance, test anxiety, rehearsal, elaboration, organization, critical thinking, metacognitive selfregulation, time and study environment, effort regulation, peer learning, and help-seeking. The answer choices are in the form of a scale with a score range of 1 to 6 (strongly disagree to agree strongly). The MSLQ instrument has been used extensively on a sample of students in various countries and can be used as an overall instrument or using only separate subscales such as the SR Metacognitive subscale (Bartels \& Magun-Jackson, 2009; Credé \& Phillips, 2011; Dunn et al., 2012). This study uses only one sub-scale: metacognitive selfregulation (SR metacognitive). This sub-scale is one of the essential components in selfregulation in learning. This scale measures three activities, namely planning, monitoring, and regulation. Activities planning, for example, setting goals, analyzing tasks, and prior knowledge to organize and understand learning material more efficiently. Monitoring includes activities to keep attention while reading the material, making questions to help Regulatory understanding activities make continuous adjustments to their cognitive activities to stay connected with task $y$ faced. In this study, the internal consistency value of the SR metacognitive scale with Cronbach's Alpha was 0.78. An example of an SR metacognitive item is, for example: "I try to change my way of learning to suit the teaching style of the lecturer."

In identifying the type of GO used the Achievement Goal Questionnaire instrument (AGQ; Elliot \& McGregor, 2001). This questionnaire consists of 12 statements divided into three, each measuring four types of GO: mastery approach, mastery avoidance, performance approach, and performance-avoidance. The range of answer choices ranges from 1 (strongly disagree) to 7 (strongly agree). During the construction of this measuring 
instrument, the internal consistency of the four GO types ranged from 0.82 to 0.96 (Elliot \& McGregor, 2001). In this study, the calculation of internal consistency with Cronbach's Alpha obtained for each type of GO is 0.73 (mastery approach), 0.82 (mastery avoidance), 0.84 (performance approach), and 0.66 (performance-avoidance). This figure reflects instrument reliability ranging from moderate to high (Hinton, et al., 2004). Descriptive statistics analyzed data to determine the distribution of variable data, namely each type of GO and metacognitive SR. In addition, multiple regression analysis was used to see the effect of the four types of GO on SR metacognition. Next, we want to know which type of GO is the strongest predictor of SR metacognition.

\section{Result and Discussion}

\section{Results}

To simplify data analysis, the raw data of each variable was processed descriptively with the help of SPSS (Statistical Product and Service Solution) version 25 to obtain the total mean and standard deviation scores. The descriptive statistical analysis resulted in the average total score of the four types of GO and metacognitive SR. The GO type of students with the highest total average score is performance-avoidance, while the performance approach and mastery avoidance have the same average value, and the mastery approach has the lowest average value. Meanwhile, the mean total score of SR metacognitive was $52.89(S D=5.48)$. Further statistical analysis with inferential statistics, namely t-test and multiple regression analysis, also used the help of SPSS version 25 . The test of mean differences on descriptive data based on sex on the metacognitive variable SR showed the mean total score $=53.26(S D=5.21)$ for female students and $51.45(S D=6.27)$ for male students. The t-test calculation results showed a significant difference between the two SR metacognitive total scores $(\mathrm{t}=-2.39, \mathrm{p}<0.05)$. Prior to the multiple regression analysis, the assumptions of normality, linearity, and multicollinearity were tested. Normality test using Kolmogorov-Smirnov produces an Asymp.Sig (2-tailed) value of 0.200 , or $>0.05$, means the data is usually distributed. The linearity test on all types of GO on metacognitive SR showed different $F$ values, but all of them with $p$-value $<0.001$, which means they meet the assumption test. Meanwhile, the multicollinearity test on all GO types resulted in a tolerance value $>0.10$ and a variance inflation factor $(\mathrm{VIF})<10.00$, so it can be concluded that there is no multicollinearity.

The multiple regression analysis tests to determine the effect of $\mathrm{GO}$ types together on SR metacognitive obtained a value of $F=26.134, p<0.001$. It shows that the four types of GO (Mastery Approach, Mastery Avoidance, Performance Approach, and Performance Avoidance) play a significant role in SR metacognition. The values of $R=0.499$ and $R$ Square $=0.249$ indicate the contribution of the four types of $\mathrm{GO}$ together to the metacognitive SR of $24.9 \%$. The type of GO that is a predictor of SR metacognitive is performance-approach and performance-avoidance, while mastery approach and mastery avoidance do not significantly affect SR metacognition. Furthermore, to determine the amount of effective contribution of each type of GO to SR metacognitive, the two types of GO that have a significant role, namely performance-approach and performance-avoidance, each show $R$ Square values of 0.013 and 0.083 , which means that they contribute $13 \%$ and $8.3 \%$ of SR metacognitive. Meanwhile, the R Square mastery avoidance value is 0.025 and performance-avoidance is $\mathbf{0 . 0 1 1}$, or the contribution to SR metacognitive is $2.5 \%$ and $1.1 \%$ but not significant.

\section{Discussion}

In this study, the type of GO adopted by students was not categorized into one particular type of GO so that each subject had four types of GO at different levels. The GO approach with a multiple goal perspective is in the context of higher education, allowing individuals to have multiple goals. It refers to some GO studies that argue that individuals can have several types of GO at once, and these various types provide equally important information in providing feedback and regulating the learning process (Mädamürk et al., 
2021; Magni et al., 2021). Having both types of GO mastery and performance simultaneously will provide a more optimal motivational impact because it can choose certain types of GO for specific learning contexts.

Related to the data of this study, the type of GO that is a predictor for metacognitive SR are the type of GO performance, both approaches, and avoidance types. The adoption of GO performance is in line with the context of the learning environment in higher education, which is still oriented towards achieving grades/numbers, high competition, and lectures taking place in large class sizes (Hoffman et al., 2014; Stasielowicz, 2019). Thus, in this study's context of learning subjects, the GO adopted by the subject and has a role in metacognitive SR is performance. In order to achieve learning goals that demonstrate higher competence than others (performance approach) or avoid failure (performance-avoidance), students continue to plan, monitor, and regulate (Gul \& Shehzad, 2012; Honicke et al., 2020). The adoption of GO performance, both approach and avoidance in this research sample, seems to be influenced by the learning situation at hand. In line with the results of preliminary studies from this research, the condition of PJJ, which is still a new thing for students, has an impact on reducing self-confidence in their ability to understand lecture material and having anxiety about the final results of their academic achievements (Neroni et al., 2018; Yudhistira et al., 2020). Self-confidence and GO are motivational variables that play an essential role in SRL and academic achievement (Honicke et al., 2020). Various studies have found that individuals will adopt GO according to their perception of GO in the learning environment (Boden et al., 2020; Fadlelmula et al., 2015; Hofverberg \& Winberg, 2020).

Thus, when students perform metacognitive SR in their learning process, GO performance predicts their metacognition, performance approach, and performance avoidance. The results of this study are different from previous studies, which found that GO mastery was a predictor of metacognitive skills, while performance-approach and performance-avoidance had no direct or indirect influence on SR metacognitive (Al-Harthy et al., 2010; Fadlelmula et al., 2015). Several studies have proven that each type of GO has a different effect on learning strategies and achievement through dynamic interactions with various other variables (such as the level of task difficulty, class goal structure) (Hofverberg \& Winberg, 2020; Mouratidis et al., 2018). In the context of PJJ, the GO performance approach was a positive predictor of academic achievement, while GO mastery was not a predictor, and GO performance-avoidance was a negative predictor of academic achievement (Neroni et al., 2018).

In this study, the academic achievement variable was not included. Therefore, the result of the study that GO performance-avoidance is a strong predictor of SR metacognitive needs to be studied further on its impact on achievement. Previous studies have consistently found adverse effects of this type of GO on maladaptive behavioral patterns and achievement (Darnon et al., 2007; Hulleman et al., 2010). However, they did not find a relationship between SR metacognition and achievement (Fadlelmula et al., 2015). In the context of online learning, various studies have found varying effects of SR metacognition on achievement (Broadbent \& Poon, 2015).

Related to the highest average GO performance-avoidance score in this study, it is necessary to examine whether the learning environment in the context of PJJ stimulates students to adopt GO performance-avoidance. A high level of task difficulty, low confidence in abilities, and fear of failure are identified to stimulate GO performance. This study found different types of GO from other studies as metacognitive predictors of SR. Previous research found that GO that acts as a metacognitive predictor of SR is the mastery and performance approaches. In this study that uses the context of the PJJ model, the type of GO performance-avoidance is also a metacognitive predictor of SR and the performance approach. However, this study cannot prove the effect of performance-avoidance on achievement mediated by metacognitive SR because it does not include achievement as a research variable. It is one of the limitations of this study. Regarding the implications of this research, teachers should make changes to the structure of class goals that stimulate the adoption of the mastery approach and performance approach as a type of GO that is more 
adaptive to achieve more optimal learning achievement. Meanwhile, considering that various studies have found maladaptive effects of GO performance-avoidance, such as procrastination, decreased persistence in experiencing task difficulties, and achievement, the learning environment should not stimulate performance-avoidance adoption (Boden et al., 2020).

\section{Conclusions and Suggestions}

The results of this study have not been able to explain why the type of GO mastery which in many studies GO is considered the most adaptive to SRL, but this study was not a significant predictor of metacognitive SR. It is related to the limitations of this study which did not use other sub-scales in the SRL (only metacognitive sub-scales) so that it was unable to explain how the dynamics of multiple goals on the SRL sub-scale as a whole were. Therefore, for further research, it is recommended to use the full SRL scale and add other variables such as academic achievement, task characteristics, or class structure so that other statistical analyzes can be used to describe the dynamics of the relationship between variables more comprehensively.

\section{References}

Adedoyin, O. B., \& Soykan, E. (2020). Covid-19 pandemic and online learning: the challenges and opportunities. In Interactive Learning Environments. https://doi.org/10.1080/10494820.2020.1813180.

Ahmed, W. (2017). Motivation and self-regulated learning: A multivariate multilevel analysis. International Journal of Psychology and Educational Studies, 4(3). https://doi.org/10.17220/ijpes.2017.03.001.

Al-Harthy, I. S., Was, C. A., \& Isaacson, R. M. (2010). Goals, efficacy and metacognitive selfregulation: A path analysis. International Journal of Education, 2(1). https://doi.org/10.5296/ije.v2i1.357.

Anthonysamy, L., Koo, A. C., \& Hew, S. H. (2020). Self-regulated learning strategies and non-academic outcomes in higher education blended learning environments: A one decade review. Education and Information Technologies, 1. https://doi.org/10.1007/s10639-020-10134-2.

Bartels, J. M., \& Magun-Jackson, S. (2009). Approach-avoidance motivation and metacognitive self-regulation: The role of need for achievement and fear of failure. Learning and Individual Differences, 19(4), 459-463. https://doi.org/10.1016/j.lindif.2009.03.008.

Bittner, J. V. (2021). Goal interruptions and task performance: The additional influence of goal orientations. Learning and Motivation, 76. https://doi.org/10.1016/j.Imot.2021.101768.

Boden, K. K., Zepeda, C. D., \& Nokes-Malach, T. J. (2020). Achievement goals and conceptual learning: An examination of teacher talk. Journal of Educational Psychology, 112(6), 1221-1242. https://doi.org/10.1037/edu0000421.

Broadbent, J., \& Poon, W. (2015). Self-regulated learning strategies \& academic achievement in online higher education learning environments: A systematic review. The Internet and Higher Education, 27. https://doi.org/10.1016/j.iheduc.2015.04.007.

Broadbent, Jaclyn. (2017). Comparing online and blended learner's self-regulated learning strategies and academic performance. Internet and Higher Education, 33, 24-32. https://doi.org/10.1016/j.iheduc.2017.01.004.

Credé, M., \& Phillips, L. A. (2011). A meta-analytic review of the Motivated Strategies for Learning Questionnaire. Learning and Individual Differences, 21(4), 337-346. https://doi.org/10.1016/j.lindif.2011.03.002.

Darnon, C., Harackiewicz, J. M., Butera, F., Mugny, G., \& Quiamzade, A. (2007). Performance-approach and performance-avoidance goals: When uncertainty makes 
a difference. Personality and Social Psychology Bulletin, 33(6), 813-827. https://doi.org/10.1177/0146167207301022.

Dent, A. L., \& Koenka, A. C. (2016). The relation between self-regulated learning and academic achievement across childhood and adolescence: A meta-analysis. Educational Psychology Review, 28(3). https://doi.org/10.3389/fpsyg.2017.00422.

Dewi, W. A. F. (2020). Dampak Covid-19 Terhadap Implementasi Pembelajaran Daring Di Sekolah Dasar. Jurnal IImu Pendidikan, 2(1). https://doi.org/10.31004/edukatif.vi1.89.

Dunn, K. E., Lo, W. J., Mulvenon, S. W., \& Sutcliffe, R. (2012). Revisiting the Motivated Strategies for Learning Questionnaire: A Theoretical and Statistical Reevaluation of the Metacognitive Self-Regulation and Effort Regulation Subscales. Educational and Psychological Measurement, 72(2), 312-331. https://doi.org/10.1177/0013164411413461.

Elliot, A. J., \& McGregor, H. A. (2001). A $2 \times 2$ achievement goal framework. Journal of Personality and Social Psychology, 80(3), 501-519. https://doi.org/10.1037/00223514.80.3.501.

Etikan, I., Musa, S. A., \& Alkassim, R. S. (2016). Comparison of convenience sampling and purposive sampling. American Journal of Theoretical and Applied Statistics, 5(1), 1-4. https://doi.org/10.11648/j.ajtas.20160501.11.

Fadlelmula, F. K., Cakiroglu, E., \& Sungur, S. (2015). Developing a structural model on the relationship among motivational beliefs, self-regulated learning strategies, and achievement in mathematics. International Journal of Science and Mathematics Education, 13(6), 1355-1375. https://doi.org/10.1007/s10763-013-9499-4.

Fitriyani, Y., Fauzi, I., \& Sari, M. Z. (2020). Motivasi Belajar Mahasiswa Pada Pembelajaran Daring Selama Pandemik Covid-19. Profesi Pendidikan Dasar, 7(1), 121-132. https://doi.org/10.23917/ppd.v7i1.10973.

Gul, F., \& Shehzad, S. (2012). Relationship between metacognition, goal orientation and academic achievement. Procedia - Social and Behavioral Sciences, 47, 1864-1868. https://doi.org/10.1016/j.sbspro.2012.06.914.

Hamidaturrohmah, \& Mulyani, T. (2020). Strategi Pembelajaran Jarak Jauh Siswa Berkebutuhan Khusus Di SD Inklusi Era Pandemi COVID-19. Elementary: Islamic Teacher Journal, 10(1). https://doi.org/10.21043/elementary.v8i2.7907.

Hapsari, T. P. R. N., \& Fitria, A. S. (2020). Efektivitas Pembelajaran Daring Mata Kuliah Evaluasi Pengajaran Bahasa Dan Sastra Indonesia Masa Pandemi Covid-19. Jurnal IImiah SEMANTIKA, 2(01), 11-20. https://doi.org/10.46772/semantika.v2i01.259.

Hinton, P.R., Brawnlow, C,, McMurray, I., Cozen, B. (2004). SPSS Explained. Roudledge.

Hoffman, R. L., Hudak-Rosander, C., Datta, J., \& Morris, J. B. (2014). Goal orientation in surgical residents: a study of the motivation behind learning. Journal of Surgical Research, 190(2). https://doi.org/10.1016/j.jss.2014.01.005.

Hofverberg, A., \& Winberg, M. (2020). Achievement goals and classroom goal structures: Do they need to match? Journal of Educational Research, 113(2), 145-162. https://doi.org/10.1080/00220671.2020.1759495.

Honicke, T., Broadbent, J., \& Fuller-Tyszkiewicz, M. (2020). Learner self-efficacy, goal orientation, and academic achievement: exploring mediating and moderating relationships. Higher Education Research and Development, 39(4), 689-703. https://doi.org/10.1080/07294360.2019.1685941.

Hulleman, C. S., Schrager, S. M., Bodmann, S. M., \& Harackiewicz, J. M. (2010). A metaanalytic review of achievement goal measures: Different labels for the same constructs or different constructs with similar labels? Psychological Bulletin, 136(3), 422-449. https://doi.org/10.1037/a0018947.

Kuo, Y. C., Walker, A. E., Schroder, K. E. E., \& Belland, B. R. (2014). Interaction, internet self-efficacy, and self-regulated learning as predictors of student satisfaction in online education courses. Internet and Higher Education, 20, 35-50. https://doi.org/10.1016/j.iheduc.2013.10.001.

Lin, G.-Y. (2020). Scripts and mastery goal orientation in face-to-face versus computermediated collaborative learning: Influence on performance, affective and motivational 
outcomes, and social ability. Computers \& Education, 143. https://doi.org/10.1016/j.compedu.2019.103691.

Maatuk, A. M., Elberkawi, E. K., Aljawarneh, S., Rashaideh, H., \& Alharbi, H. (2021). The COVID-19 Pandemic and E-learning: Challenges and Opportunities from the Perspective of Students and Instructors. Journal of Computing in Higher Education, 1-18. https://doi.org/10.1007/s12528-021-09274-2.

Mädamürk, K., Tuominen, H., Hietajärvi, L., \& Salmela-Aro, K. (2021). Adolescent students' digital engagement and achievement goal orientation profiles. Computers \& Education, 161. https://doi.org/10.1016/j.compedu.2020.104058.

Magni, F., Gong, Y., \& Chao, M. M. (2021). A longitudinal examination of the reciprocal relationship between goal orientation and performance: The mediating role of selfefficacy. Personality and Individual Differences, 179. https://doi.org/10.1016/j.paid.2021.110960.

Mawardi. (2020). Keefektifan Flexible Learning dalam Menumbuhkan Self-Regulated Learning dan Hasil Belajar Mahasiswa PGSD. Scholaria: Jurnal Pendidikan Dan Kebudayaan, 10(3). https://doi.org/10.24246/j.js.2020.v10.i3.p251-262.

Minelli, E., Alerasoul, S. A., Afeltra, G., Hakala, H., \& Minelli, E. (2021). Organisational learning, learning organisation, and learning orientation: An integrative review and framework. Human Resource Management Review. https://doi.org/10.1016/j.hrmr.2021.100854.

Moning, J., \& Roelle, J. (2021). Self-regulated learning by writing learning protocols: Do goal structures matter? Learning and Instruction, 75. https://doi.org/10.1016/j.learninstruc.2021.101486.

Mouratidis, A., Michou, A., Demircioğlu, A. N., \& Sayil, M. (2018). Different goals, different pathways to success: Performance-approach goals as direct and mastery-approach goals as indirect predictors of grades in mathematics. Learning and Individual Differences, 61, 127-135. https://doi.org/10.1016/j.lindif.2017.11.017.

Neroni, J., Meijs, C., Leontjevas, R., Kirschner, P. A., \& de Groot, R. H. M. (2018). Goal orientation and academic performance in adult distance education. International Review of Research in Open and Distance Learning, 19(2), 192-208. https://doi.org/10.19173/irrodl.v19i2.3440.

Panadero, E. (2017). A review of self-regulated learning: Six models and four directions for research. In Frontiers in Psychology (Vol. 8, Issue APR). https://doi.org/10.3389/fpsyg.2017.00422.

Permai, B., Clement, S., \& Yunus, M. (2021). English Teaching Amidst the COVID-19 Pandemic: Teacher Issues and Challenges Community of Inquiry ( COL ). Malaysian Journal of Social Sciences and Humanities (MJSSH), 6(5), 103-116. https://doi.org/10.47405/mjssh.v6i5.797 Malaysian.

Pintrich, P. R. R., Smith, D., Garcia, T., \& McKeachie, W. (1991). A manual for the use of the Motivated Strategies for Learning Questionnaire (MSLQ). Ann Arbor. Michigan, 48109(August 2016). https://doi.org/ED338122.

Ranti, M. G., Budiarti, I., \& Trisna, B. N. (2017). Pengaruh Kemandirian Belajar (Self Regulated Learning) Terhadap Hasil Belajar Mahasiswa Pada Mata Kuliah Struktur Aljabar. Math Didactic, 3(1), 75-83. https://doi.org/10.33654/math.v3i1.57.

Reni, Y. M., \& Kuswandi, D. (2018). Pengaruh Strategi Pembelajaran dan Self Regulated Learning Terhadap Hasil Belajar. JINOTEP (Jurnal Inovasi Dan Teknologi Pembelajaran), 10(1). https://doi.org/10.17977/um031v4i12017p047.

Sadikin, A., \& Hamidah, A. (2020). Pembelajaran Daring di Tengah Wabah Covid-19. Biodik, 6(2), 109-119. https://doi.org/10.22437/bio.v6i2.9759.

Sangsawang, T. (2020). An instructional design for online learning in vocational education according to a self-regulated learning framework for problem solving during the covid19 crisis. Indonesian Journal of Science and Technology, 5(2), 283-198. https://doi.org/10.17509/ijost.v5i2.24702.

Serdyukov, P. and Hill, R. A. (2013). Flying with clipped wings: Are students independent in online college classes? Journal of Research in Innovative Teachibg, 6(1), 54-67. 
Simanjuntak, S. Y., Kismartini, Dwimawanti, I. H., \& Hidayatullah, M. A. (2020). Respons Guru Terhadap Kebijakan Pembelajaran Jarak Jauh Selama Pandemi Covid-19. Jurnal Ilmiah Pendidikan Citra Bakti, 7(2), 125-136. https://doi.org/10.38048/jipcb.v7i2.108.

Stasielowicz, L. (2019). Goal orientation and performance adaptation: A meta-analysis. Journal of Research in Personality, 82. https://doi.org/10.1016/j.jrp.2019.103847.

Suriadi, H. J., Firman, F., \& Ahmad, R. (2021). Analisis Problema Pembelajaran Daring Terhadap Pendidikan Karakter Peserta Didik. Edukatif: Jurnal IImu Pendidikan, 3(1), 165-173. https://doi.org/10.31004/edukatif.v3i1.251.

Van Alten, D. C., Phielix, C., Janssen, J., \& Kester, L. (2020). Self-regulated learning support in flipped learning videos enhances learning outcomes. Computers \& Education, 158. https://doi.org/10.1016/j.compedu.2020.104000.

Vrieling, E. M., Bastiaens, T. J., \& Stijnen, S. (2012). Effects of increased self-regulated learning opportunities on student teachers' metacognitive and motivational development. International Journal of Educational Research, 53. https://doi.org/10.1016/j.ijer.2012.03.014.

Winne, P. H. (2015). Self-Regulated Learning. In International Encyclopedia of the Social \& Behavioral Sciences: Second Edition (pp. 535-540). https://doi.org/10.1016/B978-008-097086-8.25091-5.

Yoga Purandina, I. P., \& Astra Winaya, I. M. (2020). Pendidikan Karakter di Lingkungan Keluarga Selama Pembelajaran Jarak Jauh pada Masa Pandemi COVID-19. Cetta: Jurnal IImu Pendidikan, 3(2), 270-290. https://doi.org/10.37329/cetta.v3i2.454.

Yudhistira, S., Deasyanti, \& Muzdalifah, F. (2020). Analisis model pengaruh goal orientation, general self-efficacy dan jenis kelamin terhadap self-regulated learning dalam pembelajaran jarak jauh. Jurnal Muara IImu Sosial, Humaniora, Dan Seni, 4(2), 358367. https://doi.org/10.24912/jmishumsen.v4i2.8849.2020.

Yudiawan, A. (2020). Belajar Bersama COVID 19: Evaluasi Pembelajaran Daring Era Pandemi di Perguruan Tinggi Keagamaan Islam Negeri, Papua Barat. Al-Fikr : Jurnal Pendidikan Islam, 6(1). https://doi.org/10.32489/alfikr.v6i1.64. 